\title{
Surface deformation related to kink-folding above an active fault: Evidence from geomorphic features and co-seismic slips
}

\author{
Kuang-Yin Lai ${ }^{\mathrm{a}}$, Yue-Gau Chen ${ }^{\mathrm{a}, *}$, Jih-Hao Hung ${ }^{\mathrm{b}}$, John Suppe ${ }^{\mathrm{c}}$, \\ Li-Fan Yue ${ }^{c}$, Ya-Wen Chen ${ }^{\mathrm{a}}$ \\ ${ }^{a}$ Institute of Geosciences, National Taiwan University, P.O. Box 13-318, Taipei 106, Taiwan \\ ${ }^{\mathrm{b}}$ Institute of Geophysics, National Central University, Chungli 320, Taiwan \\ ${ }^{\mathrm{c}}$ Department of Geosciences, Princeton University, Princeton, NJ 08544, USA
}

Available online 9 December 2005

\begin{abstract}
By means of a geomorphological study using $40 \mathrm{~m}$ digital elevation model, structural reconstruction by field data, and related geodetic results, we reevaluate the geomorphic features in the Hsinshe area, where multi-step terraces have been previously documented and supposedly provide more information of the neotectonic history. Our results show that two kink-shaped scarps can be discriminated from other terrace risers, which are probably formed by folding instead of faulting as suggested by previous researchers. Two E-Wreconstructed hanging wall cross sections in the north and south show that the fault plane of Chelungpu fault flattens to the east and sinks to the south, creating a monoclinal hanging wall resembling a quarter hemisphere in terms of a 3D model. We propose a kinetic model to explain the surface monocline fold: it is developed when the fault plane presents a fault-bend, such as the case along the Chelungpu fault at Hsinshe. The co-seismic deformation from the 1999 Chi-Chi earthquake demonstrates that the model is probably valid. Furthermore, the higher terrace showing larger deformation indicates the influences of active structures on terraces have continuously acted for a long time. The westward tilting of the hanging wall terraces result from the action of the Chelungpu fault and its related structural geometry. Based on the optical-stimulated-luminescence age of $55.0 \pm 12.6 \mathrm{ka}$ of the highest terrace, we can compute the vertical rates across the main thrust and fold scarp in the hanging wall as 7.0 and $2.5 \mathrm{~m} / \mathrm{kyr}$, respectively.
\end{abstract}

(C) 2005 Elsevier Ltd and INQUA. All rights reserved.

\section{Introduction}

The surface rupture of the 21 September 1999 earthquake $\left(M_{\mathrm{w}} 7.6\right)$ is mainly distributed in a general $\mathrm{N}-\mathrm{S}$ direction along the Chelungpu fault in central Taiwan, transitional to a complex E-W and NE-SW trending segments in its northern end (Fig. 1a). The study area, Hsinshe, is located in the hanging wall and surrounded by the northern segment of the 1999 surface rupture; although no evident surface rupture was reported. However, it still suffered serious damage due to the minor hanging wall deformations. The hanging wall deformation is in response to the fault geometry. Thus, to understand the fault geometry, landforms could provide essential information, whether the behavior of the active fault is creeping or episodic. Widely distributed multi-step terraces have been

${ }^{*}$ Corresponding author. Tel.: + 886223697648 ; fax: +886223644625 .

E-mail address: ygchen@ntu.edu.tw (Y.-G. Chen). previously documented in Hsinshe (Lin, 1957; Ho and Tan, 1960; Ku, 1963; Hsu, 1974; Shih et al., 1986). To determine the fault geometry, related faulting behavior and slip rate of the Chelungpu fault, we reexamined the deformations recorded on the terrace surface using geomorphology, structural geology, geodesy, and geochronology. We used the $40 \mathrm{~m}$ digital elevation model (DEM) of Taiwan and field investigation to map the distribution and deformation of terraces, and thereby active structures can be identified. Furthermore, we compared these geomorphic features with the co-seismic deformation data of the 1999 Chi-Chi earthquake to discuss the relationship between surface deformation and fault behavior.

\section{Tectonic background and geological setting}

Taiwan is located at a junction point of two active plate boundaries, the oceanic Philippine Sea plate and the 


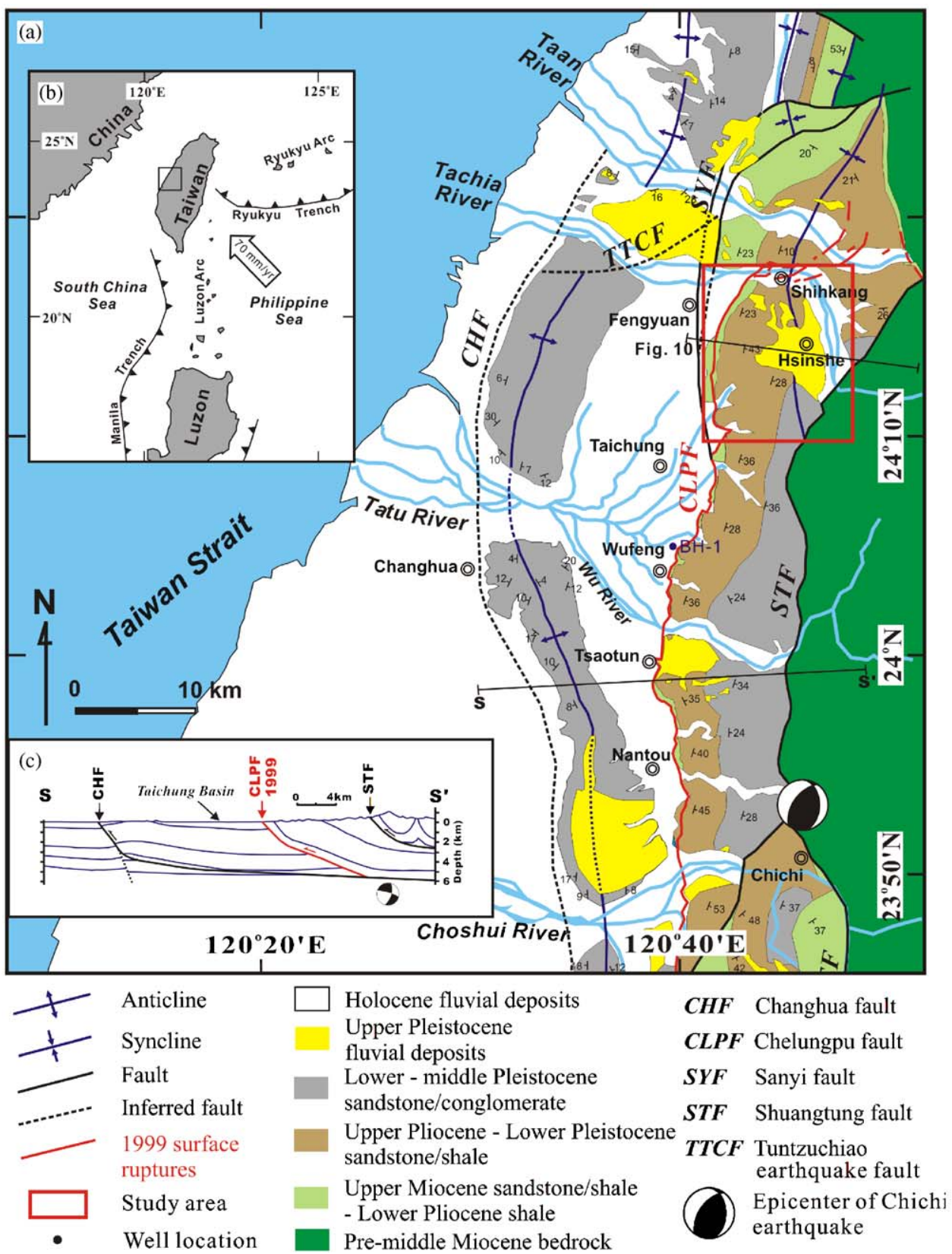

Fig. 1. (a) Geologic map of western-central Taiwan showing major structures and also 1999 surface ruptures of Chi-Chi earthquake (after Chen et al., 2001). (b) Current tectonic environments of Taiwan, where the arc-continent collision has occurred since late Miocene and is still on-going based on that the Philippine Sea plate is moving northeastward with a speed of $70 \mathrm{~mm} / \mathrm{yr}$ (Ho, 1982; Teng, 1990). (c) Cross section S-S', a published seismic profile, shows the fold-and-thrust system in central Taiwan consists of three major east-dipping-imbricated thrust faults, i.e., Changhua, Sanyi-Chelungpu, and Shungtung fault from western deformation front mountainward (Chiu, 1971).

Eurasian plate, where two arc-trench systems coexist with different subduction polarities (Ho, 1982; Teng, 1990, Fig. 1b). The Ryukyu arc, located in the north, is created by underplating the Philippine Sea plate beneath the Eurasian plate. Located in the south is the Luzon arc, which is created by the South China Sea (marginal sea of Eurasian continent) plate subducting under the Philippine Sea plate (Ho, 1982; Teng, 1990, Fig. 1b). The collision occurred when the Luzon arc approached the Ryukyu trench and consequently built up the Taiwan mountain belt. This has been confirmed as an on-going event by recently published Global Positioning System (GPS) data that demonstrate the entire island is still moving westward with respect to the Eurasian continental margin about $56-82 \mathrm{~mm} / \mathrm{yr}$ ( $\mathrm{Yu}$ et al., 1997). The foreland of the foldand-thrust system in central Taiwan comprises three major east-dipping imbricated thrust faults, the Changhua, SanyiChelungpu, and Shungtung fault, from the western deformation front mountainward (Chiu, 1971, Fig. 1c). The Chelungpu fault has thrusted over the Pleistocene strata in the footwall with a fault plane parallel to the Pliocene strata in the hanging wall and dipping $\sim 30^{\circ}$ to the 
east (Meng, 1963; Chang, 1971). The fault geometry has been reconstructed showing a thrust ramp in the shallow crust and a decollement parallel to the bedding in depth (Davis et al., 1983).

Besides the terrace deposits, the bedrock of the study area is mainly composed of strata deposited from late Pliocene to middle Pleistocene. Furthermore, the westernmost edge contains the Chinshui shale, a muddy formation of several hundred meters in thickness, which was deposited in early Pliocene. The 1999 earthquake fault, the Chelungpu fault, utilizes this shale as the sliding plane. Structurally, the study area is bounded by the
Chelungpu fault and Shuangtung fault to the west and east, respectively. Between the two thrusts is a synform, gradually becoming tighter northward (Fig. 1a).

\section{Geomorphic features and active structures of the terraces}

The main drainage flowing in the study area is the Tachia River (Figs. 1 and 2). The river valley was rather wide due to its strong hydraulic power, forming vast terraces in the western bank. These terraces are distributed in a somewhat rectangular area of $12 \times 8 \mathrm{~km}^{2}$. The southeastern part of the terraces shows well-preserved surfaces,

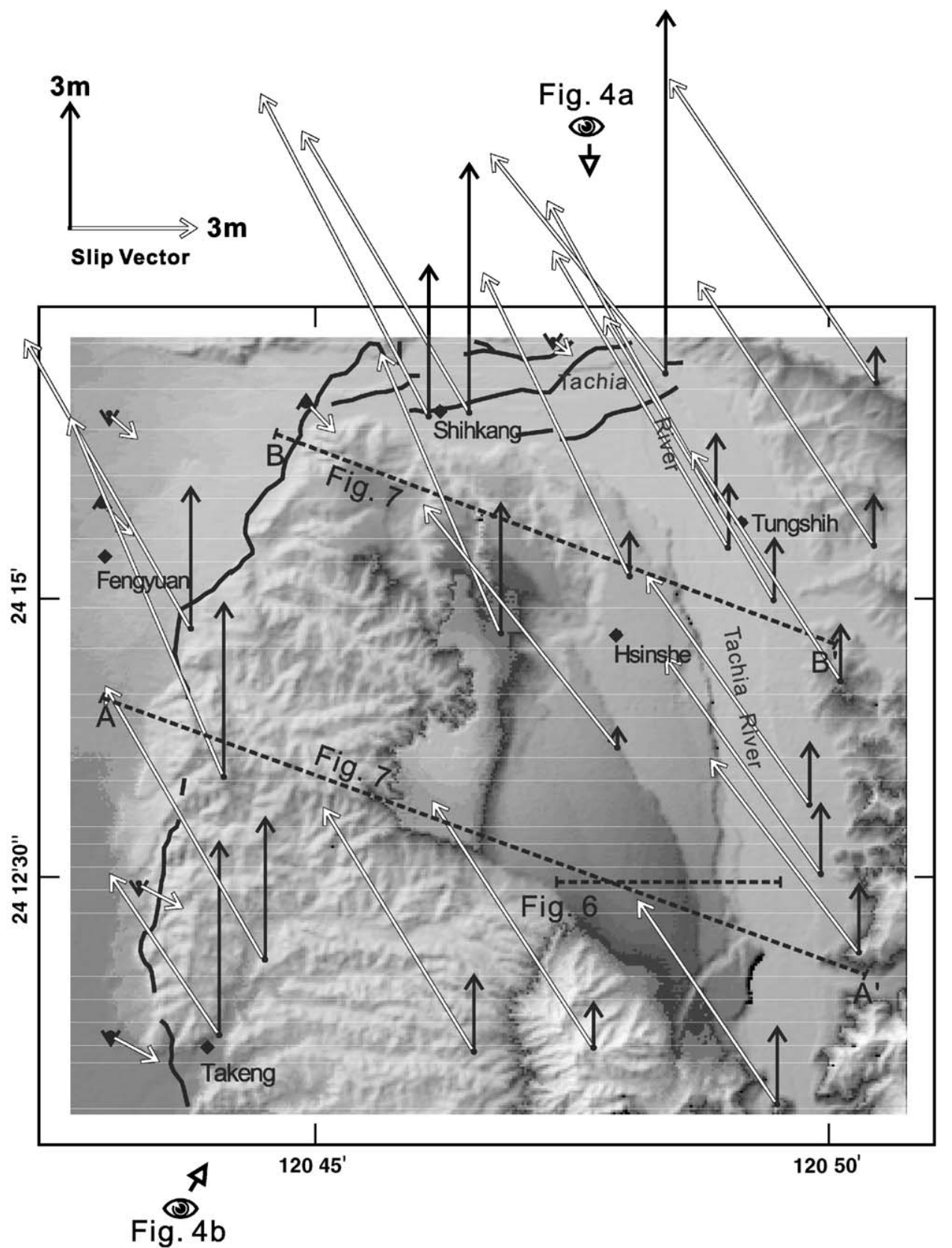

Fig. 2. Shaded relief topographic map of the study area derived from $40 \mathrm{~m}$ DEM. Solid black arrows show co-seismic vertical slips and hollow arrows show horizontal ones during 1999 Chi-Chi earthquake (LSB, 1999). Bold black lines are 1999 surface ruptures. Positions of cross sections of Figs. 6 and 7 are shown in black dashed lines. The looking directions of Fig. 4 are shown as eye symbol. 
and the northern part has been dissected by the tributaries of Tachia River. Only narrow and lower terraces are developed in the eastern bank (Figs. 2 and 3).

Multi-step terraces have been previously reported (Lin, 1957; Ho and Tan, 1960; Ku, 1963; Hsu, 1974; Shih et al., 1986). The linear scarp found on the highest terrace has been suggested as the disruption caused by the action of the active Hsinshe fault (Ku, 1963; Bonilla, 1977; Shih et al., 1986; red dash-lines in Fig. 3). Previous workers also suggested that the study area was situated in a proximal part of the alluvial fan created by the Tachia River during the Pleistocene. Subsequently, due to tectonic uplifting, the river channel incised downward and shifted northeastward, forming the terraces (Shih et al., 1986). We re-mapped the terraces using shaded relief topographic maps (Fig. 2) and 3D models produced using the $40 \mathrm{~m}$ DEM of Taiwan (Fig. 4). Based on constrained altitude in descending order, the terraces can be classified into lateritic terraces, $\mathrm{LT}_{1 \mathrm{a}}, \mathrm{LT}_{1 \mathrm{~b}}$, $\mathrm{LT}_{1 \mathrm{c}}, \mathrm{LT}_{2 \mathrm{a}}, \mathrm{LT}_{2 \mathrm{~b}}, \mathrm{LT}_{2 \mathrm{c}}, \mathrm{LT}_{2 \mathrm{a}^{\prime}}, \mathrm{LT}_{2 \mathrm{~b}^{\prime}}, \mathrm{LT}_{2 \mathrm{c}^{\prime}}, \mathrm{LT}_{3 \mathrm{a}}, \mathrm{LT}_{3 \mathrm{~b}}$, $\mathrm{LT}_{3 \mathrm{c}}$, and non-lateritic terraces, $\mathrm{FT}_{1}, \mathrm{FT}_{2}, \mathrm{FT}_{3}$. This result is internally similar to those of previous studies. By means of field surveying, we verified the terrace mapping. We, however, further regroup the lateritic terraces into three successive steps, $\mathrm{LT}_{1}\left(\mathrm{LT}_{1 \mathrm{a}}, \mathrm{LT}_{1 \mathrm{~b}}, \mathrm{LT}_{1 \mathrm{c}}\right), \mathrm{LT}_{2}\left(\mathrm{LT}_{2 \mathrm{a}}, \mathrm{LT}_{2 \mathrm{~b}}\right.$, $\left.\mathrm{LT}_{2 \mathrm{c}}, \mathrm{LT}_{2 \mathrm{a}^{\prime}}, \mathrm{LT}_{2 \mathrm{~b}^{\prime}}\right)$, and $\mathrm{LT}_{3}\left(\mathrm{LT}_{3 \mathrm{a}}, \mathrm{LT}_{3 \mathrm{~b}}, \mathrm{LT}_{3 \mathrm{c}}\right)$ based on descending order. The subscripts $\mathrm{a}, \mathrm{b}$, and $\mathrm{c}$ indicate that the terraces are supposed to form simultaneously but have later been displaced by neotectonics (Fig. 3).

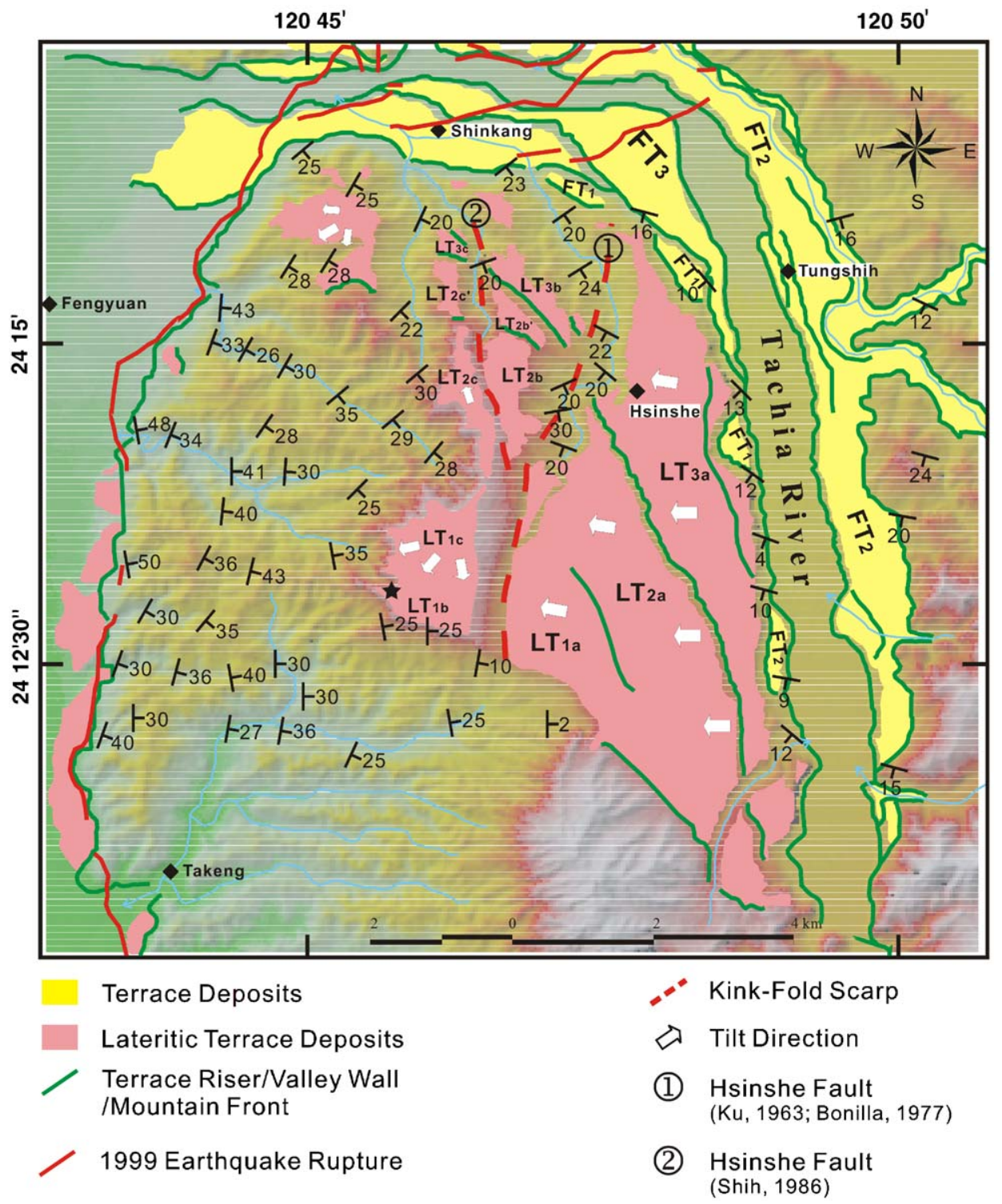

Fig. 3. A schematic map showing the terraces and active structures of study area. The terraces are distributed in the hanging wall of the Chelungpu fault, earthquake fault of 1999 Chi-Chi earthquake. Compared to Fig. 2, lateritic terraces $\left(\mathrm{LT}_{1}-\mathrm{LT}_{3}\right)$ are displaced into more subterraces by two kink structures that are previously suggested as active faults (Ku, 1963; Bonilla, 1977; Shih et al., 1986; also shown in Fig. 5). Terrace distributed in the east of kind-fold all show apparent west-dipping terrace, which is interpreted to be tectonically influenced because of its inconsistence with the orientation of the paleo-channel (also shown in Fig. 6). The asterisk shows the location of collected sample. 


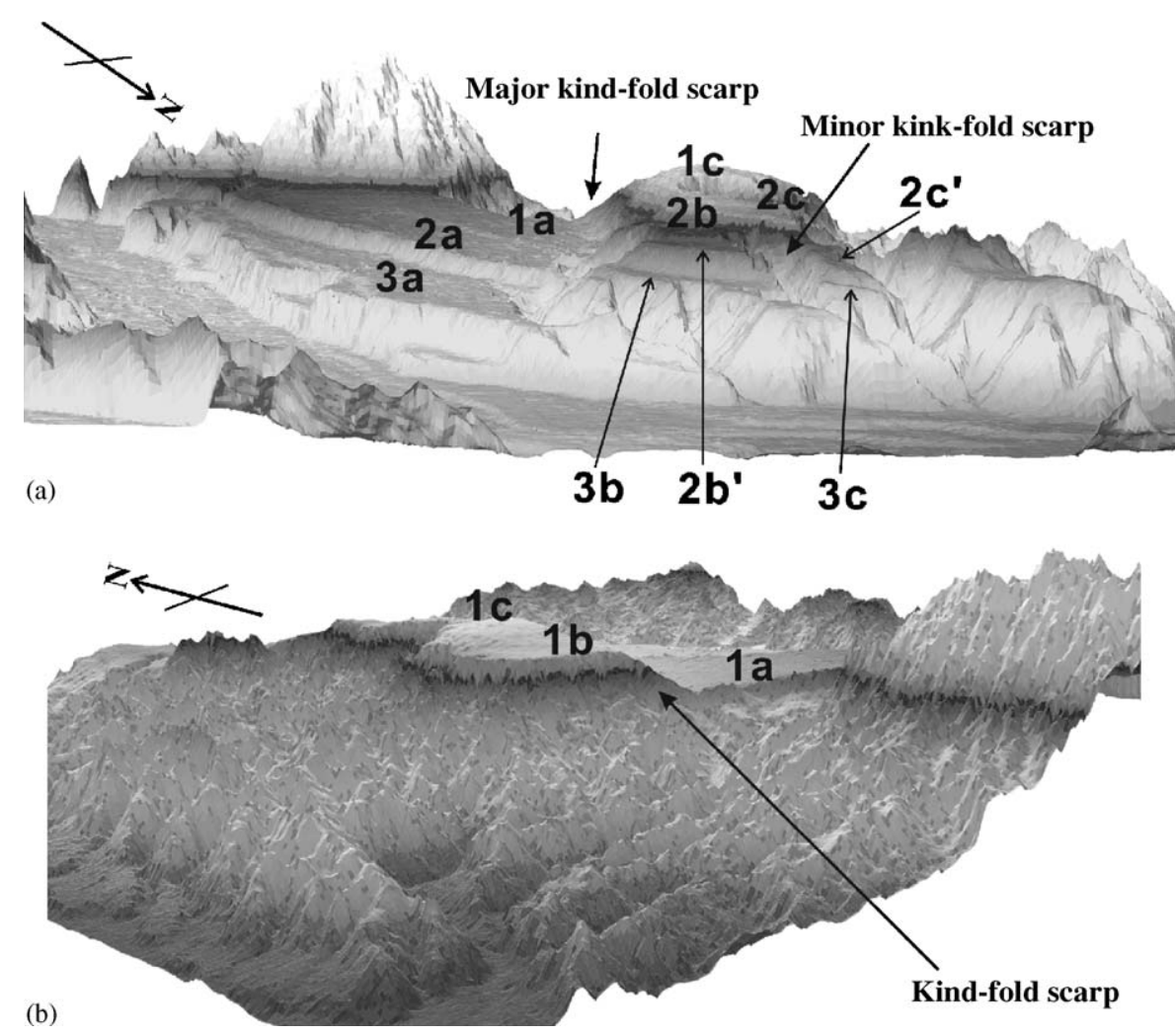

Fig. 4. Two 3D scenes showing the topography of the study area and numbers showing different lateritic terraces. (a) Looking from north obviously two scarps with kink-fold shape can be discriminated from the other terrace risers (vertical exaggeration $4.5 \times$ ). (b) Looking from south only one large kinkfold scarp is developed on Hsinshe terraces (vertical exaggeration $4 \times$ ). See the looking direction in Fig. 2.

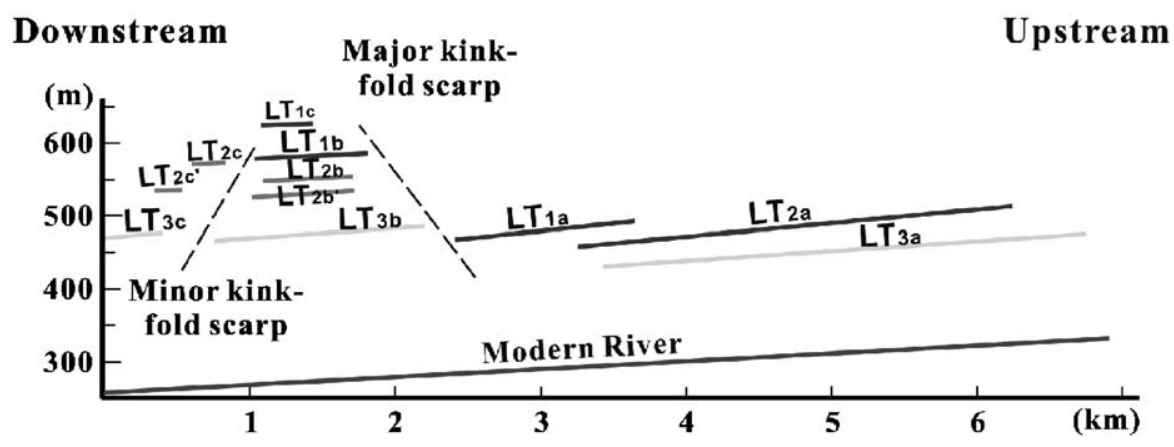

Fig. 5. Longitudinal profiles of lateritic terraces $\left(\mathrm{LT}_{1}-\mathrm{LT}_{3}\right)$. Compared to the modern Tachia River profile, the paleo-gradients corresponding to $\mathrm{LT}_{1}$, $\mathrm{LT}_{2}$, and $\mathrm{LT}_{3}$ are all quite similar to the modern river; however terraces are tectonically displaced into three sections by two active kink structures. Furthermore, higher terraces show greater displacement than lower ones $\left(\mathrm{LT}_{1}>\mathrm{LT}_{2}>\mathrm{LT}_{3}\right)$.

To diagnose the entire strain recorded by geomorphic features, we drew longitudinal profiles and compared them with the modern river profile (Fig. 5). The results show that the paleo-gradients corresponding to $\mathrm{LT}_{1}, \mathrm{LT}_{2}$, and $\mathrm{LT}_{3}$ are all quite similar to the modern river. However, the lateritic terraces are disrupted into three segments, probably due to tectonic offsets. Under virtual study on 3D topographic models, two scarps with kink-fold shape can be discriminated from the other terrace risers (Fig. 4a). The gravel beds of the terraces appear continuous, indicating no associated fault developed beneath the kink-fold scarp. Therefore, we suppose that the abovementioned scarps are probably formed by folding, instead of faulting as suggested by previous researchers $(\mathrm{Ku}, 1963$; Bonilla, 1977). The mechanism of forming this tectonic scarp will be interpreted in following discussion. Additionally, there is a single scarp in the south, which splits into two in the north. The shapes become unclear further north because they have been severely incised by the tributaries of the Tachia River.

Based on the height correlations the higher terraces show larger displacement than lower ones: $\mathrm{LT}_{1}>\mathrm{LT}_{2}>\mathrm{LT}_{3}$ 


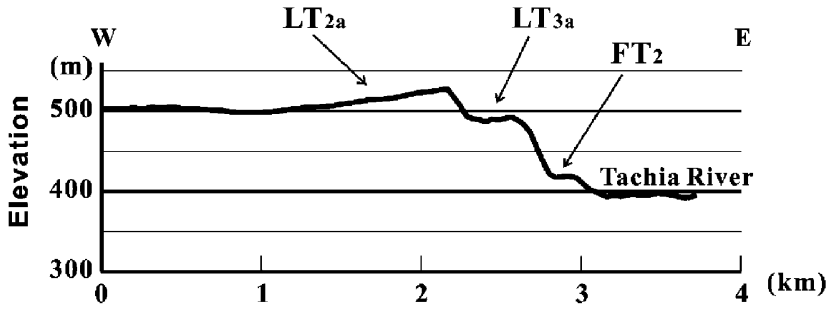

Fig. 6. Cross section showing lateritic terraces on the western bank of Tachia River has been tilted, indicating the eastern part of the lateritic terraces is undergoing a hanging wall tectonism. See location in Fig. 2.
(Fig. 5), demonstrating that these structures have been continuously active for a relatively long time. On the other hand, it also shows that all the lateritic terrace surfaces are west-dipping, further suggesting that the eastern part of the lateritic terraces is undergoing tectonic tilting (Fig. 6).

A sample collected from the sandy layer within the gravel bed of the covering deposits of $\mathrm{LT}_{1 \mathrm{~b}}$ gave an opticalstimulated-luminescence (OSL) age of $55.0 \pm 12.6 \mathrm{ka}$ (see sample location in Figs. 3 and 7; Chen et al., 2003). The above-mentioned deformations of the highest terraces are cumulated over the past $55 \mathrm{ka}$.

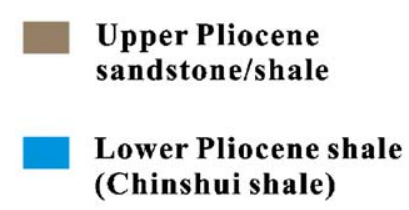

\section{Lower-middle Pleistocene sandstone/conglomerate}

\section{Lower Pleistocene} sandstone/shale

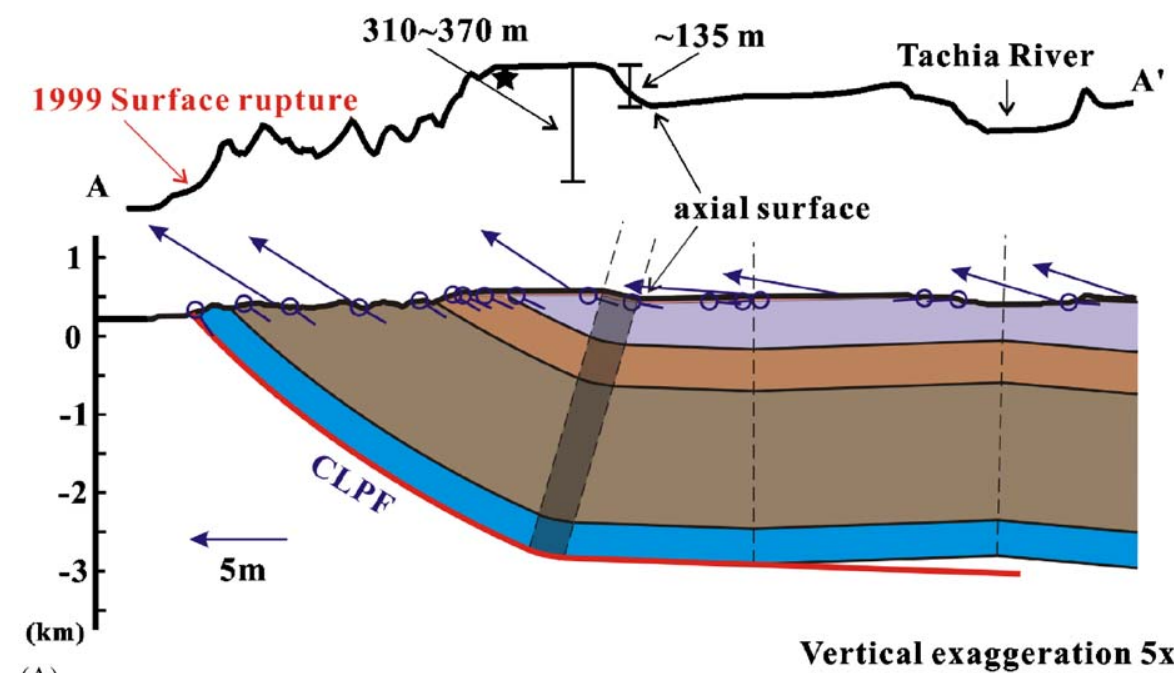

(A)

Vertical exaggeration $5 x$

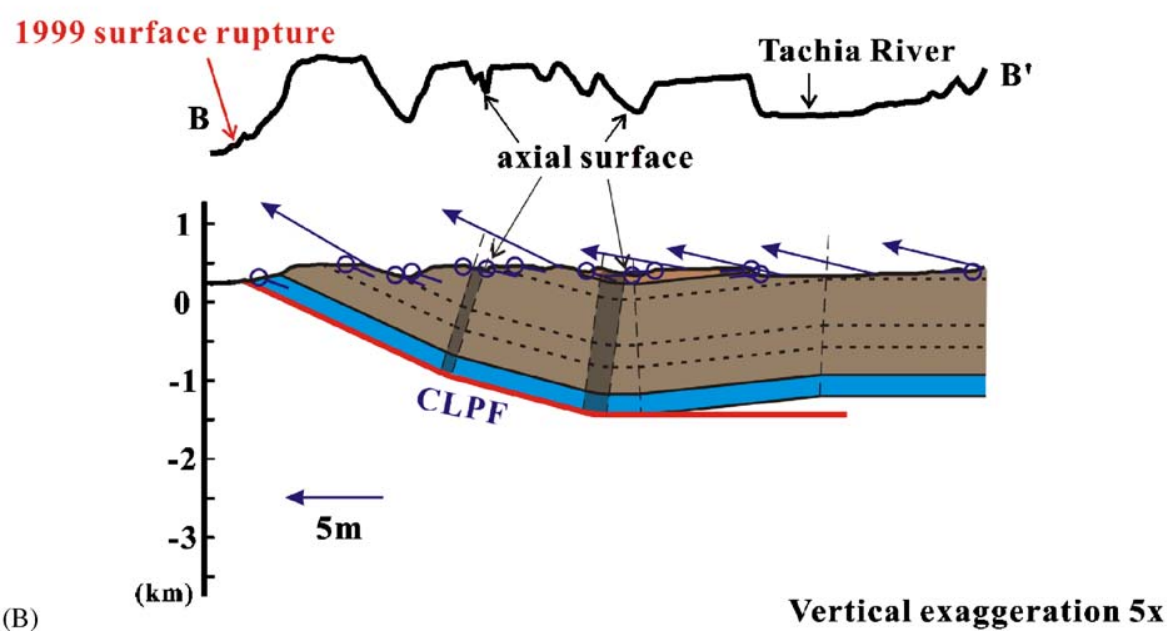

Fig. 7. Cross section A (please see Fig. 2 for the location) shows that the Chelungpu fault plane flattens at depth about $2800 \mathrm{~m}$ and the major bending of strata produces a large kink-fold scarp on the surface (see Fig. 4b) and the fold scarp height is about $135 \mathrm{~m}$. Cross section B (see Fig. 2) shows that the Chelungpu fault plane flattens at depth about $1500 \mathrm{~m}$ and the two major bends along the fault plane produce two scarps on the surface where the scarps have been dissected by tributaries of Taichia River. Based on the fault plane depths of above-mentioned two sections, it is suggested that the Chelungpu fault plane becomes shallower to the north. The elevation difference between the highest terrace $\left(\mathrm{LT}_{1}\right)$ and footwall ground surface is $310-370 \mathrm{~m}$, implying a long action history of the Chelungpu fault. The asterisk symbol shows the location of collected sample. The shaded areas show the hinge-zone (see Fig. 9) and the arrows show the co-seismic vertical uplift. 


\section{Subsurface geometry of the Chelungpu fault}

In order to understand the subsurface geology, field investigations recorded the attitudes of the strata and used the kink method to reconstruct the subsurface structural geometry. Based on previously published and Chelungpurelated profiles, the fault plane of Chelungpu fault slips along the Chinshui shale, a relatively ductile rock unit in the study area (Chou, 1971). The near-surface dip of the Chelungpu fault is $\sim 30^{\circ}$ (Meng, 1963; Chang, 1971). However, the dip changes in depth after reconstructing the entire geometry of the fault plane using regional strata attitudes (Fig. 7). We present two E-W-balanced cross sections in the north and south of the study area (Fig. 7), showing that the entire hanging wall consists of a large monoclinal syncline, and the fault plane flattens to the east. The southern-balanced cross section (Fig. 7A) shows that the Chelungpu fault plane flattens at a depth about $2.8 \mathrm{~km}$, while the northern one (Fig. 7B) flattens at about $1.5 \mathrm{~km}$. This indicates that the detachment of Chelungpu fault becomes shallower to the north and probably terminates at the Tachia river valley, as manifested by 1999 surface ruptures (CGS, 1999). Bends exist along western inclined strata of the two cross sections. The dip in section A (Fig. 7A) changes gradually from steep to gentle with only one abrupt bend. However, in section $\mathrm{B}$ there are two evident bends (Fig. 7B). The entire structure shape in the hanging wall of the Chelungpu fault is similar to a quarter hemisphere (Fig. 8). The center of hemisphere is near the flattened fault plane of section $\mathrm{A}$, on the southeastern part of the terraces (Fig. 7A), while the hemisphere rim is roughly the 1999 Chichi surface ruptures.

\section{Discussion}

\subsection{Surface monoclinal kink-fold created by underlying fault-bend}

What mechanism would form the kink-fold scarps (Figs. 3 and 4)? The scarp trace on the ground surface matches the surface projection line of the axial surface of the syncline reconstructed in the balanced cross section (Fig. 7). We tentatively suggest a kinetic model to explain this feature based on the available data (Fig. 9). In this conceptual model, the hanging wall can be divided into two parts by the syncline hinge-zone. The eastern part moves following vector $V_{1}$, while the western part slips as $V_{2} . V_{2}$ has a larger vertical and a smaller horizontal component than of the $V_{1}$. Therefore, a differential uplifting occurs across the hinge-zone, leading to formation of a scarp facing opposite to the direction of the main fault. The length and dip angle of the kink-shape reflects the ultimate strain and the changing rate of strata dip. If it is seismicassociated, we can utilize the co-seismic deformation of the surface fold to verify our kinetic model. The co-seismic deformation recorded from GPS measurements during the 1999 Chi-Chi earthquake (LSB, 1999; CGS, 1999) demonstrates that the vertical slip is greater than $3 \mathrm{~m}$ in the west of the syncline hinge plane and less than $1 \mathrm{~m}$ in the east, confirming a large vertical difference. Moreover, the

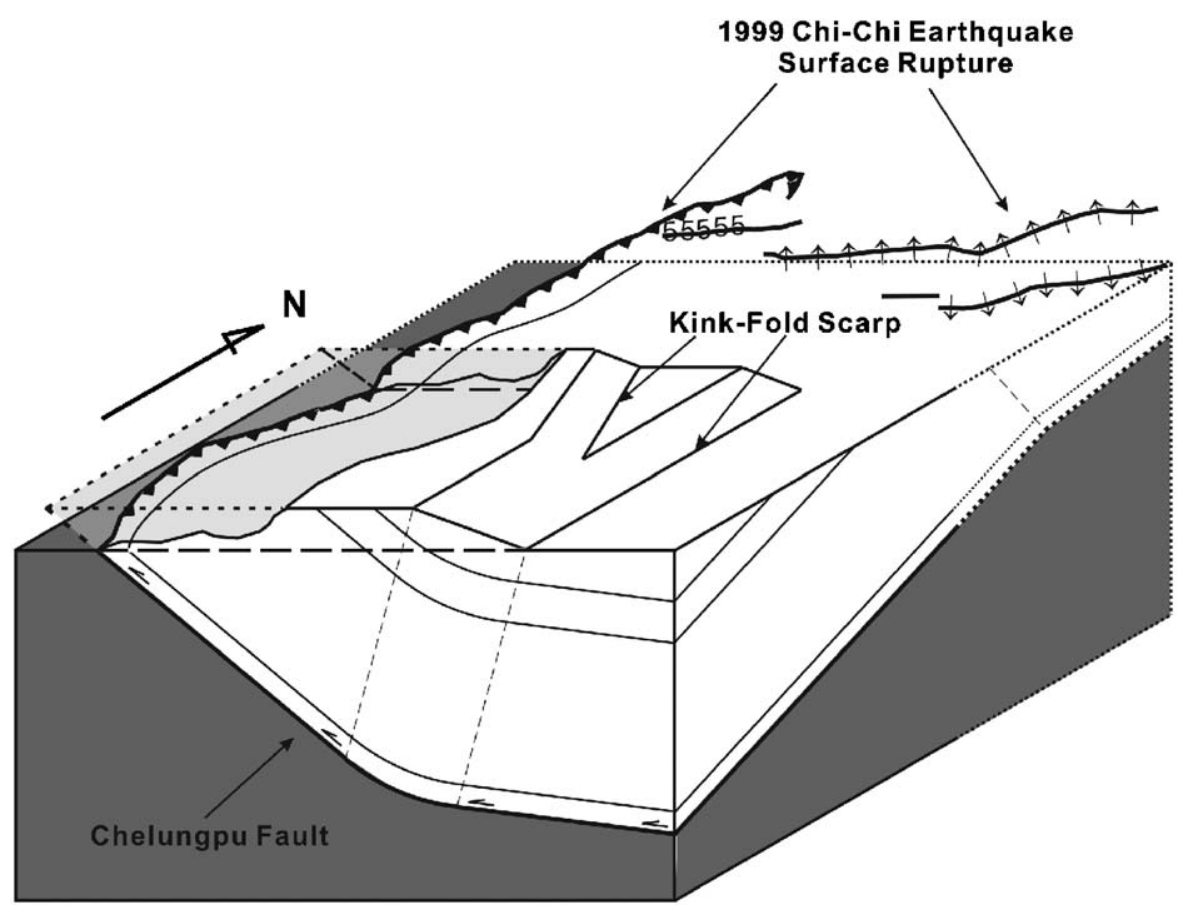

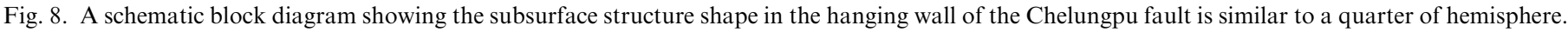

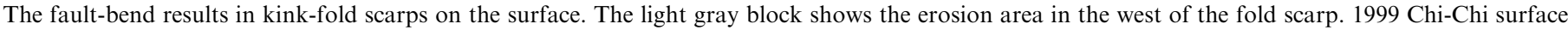
ruptures are shown in symbols of thrust and monocline based on post earthquake investigation (CGS, 1999). 
breaking line of the vertical components matches the scarp trace (Figs. 2 and 7). This co-seismic result verifies our model. A surface monocline fold can be produced if the hanging wall strata have a fault-bend, such as is the case along the Chelungpu fault at Hsinshe. Additionally, a surface scarp needs to be carefully studied, instead of simply mapping it as a consequence of active faulting.

\subsection{Other surface tilting and related subsurface structure}

Terraces, $\mathrm{LT}_{1 \mathrm{a}}, \mathrm{LT}_{2 \mathrm{a}}$, and $\mathrm{LT}_{3 \mathrm{a}}$, are all tilted to the west (Figs. 3 and 6), which is unusual if the structural geometry is similar to a general thrust sheet, an east-dipping ramp

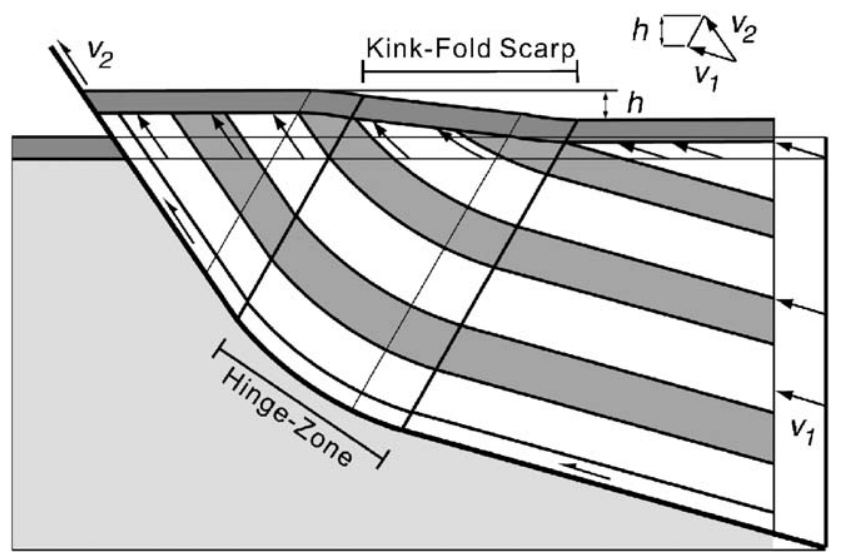

Fig. 9. A sketch of the kinetic model to explain surface monoclinal kinkfold scarps created by fault-bend beneath. $V_{1}$ and $V_{2}$ are divided by the syncline hinge-zone and $V_{2}$ has larger vertical and smaller horizontal component than of the $V_{1}$. The co-seismic differential uplifting $(h)$ to produce the surface kink-fold scarp can be estimated by slipping vectors of $V_{1}$ and $V_{2}$. connecting to a flat surface with depth mountainward. In a simple case, the strata above the flat are nearly horizontal or very gently dipping mountainward, and the corresponding ground surface therefore would not be tilted. At Hsinshe, both the terrace surface and the strata underneath dip toward the mountain front. Thus, there is probably an active structure instead of a simple flat detachment.

This feature is located within the hanging wall wedges of the Sanyi-Chelungpu fault system, and is adjacent to the fault-plane of the Shuangtung fault, although it is in the footwall (Fig. 10). The above-mentioned tilting feature can be explained either if the Sanyi fault emplaced a bend beneath or if the Shuangtung fault caused a large-scale drag on the footwall. Based on related geomorphology, however, the faults, Sanyi and Shuangtung, have both been proposed to show relatively low recent activity, unlike the Chelungpu fault (Ota et al., 2005). They hence cannot be responsible for the development of the feature on younger terraces as we found in this study. Here we propose a hypothesis that the tilting feature is caused by the singularity on the Chelungpu fault as shown in the cross section of the Sanyi-Chelungpu fault system and fault models (Figs. 10 and 11). Fault models (Yue et al., 2005; Fig. 11) indicate that a large syncline developed in the hanging wall of the Chelungpu fault which is structurally closing northward (Figs. 1 and 11). A minor anticline has developed within the syncline in response to the bump on the fault-ramp in the north and grew southward, becoming a detachment fold. It therefore grew with the slip of the Chelungpu fault and produced significant surface deformation. If this working model is true, related surface deformation should have been coseismically observed in the 1999 earthquake. This model is verified by two coseismic phenomena records of Chi-Chi earthquake
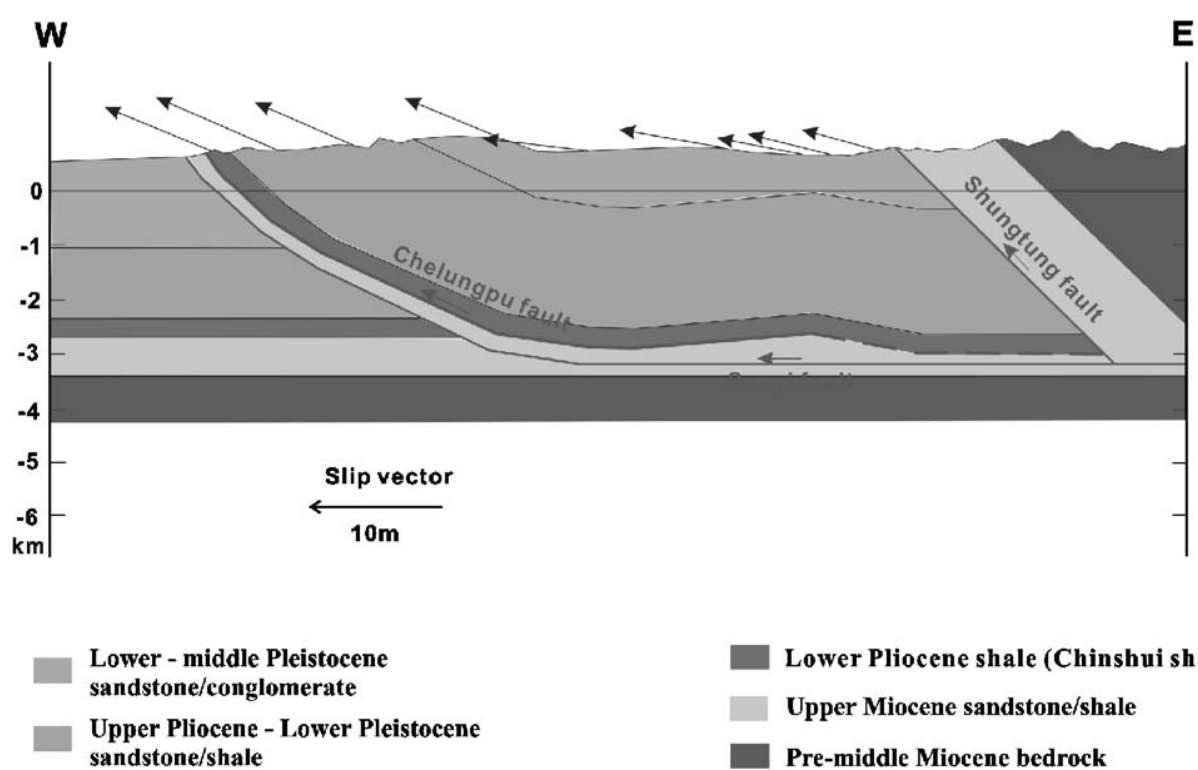

Lower Pliocene shale (Chinshui shale)

Upper Miocene sandstone/shale

Pre-middle Miocene bedrock

Fig. 10. A balanced cross section of Sanyi-Chelungpu fault system (after Hung and Suppe, 2002; Yue et al., 2005; see location in Fig. 1a) showing Chelungpu fault slips along the lower Pliocene shale (Chinshui shale) while Sanyi fault slips along the upper Miocene sandstone/shale. Blue arrows represent the projected co-seismic net slip vectors during 1999 Chi-Chi earthquake. 


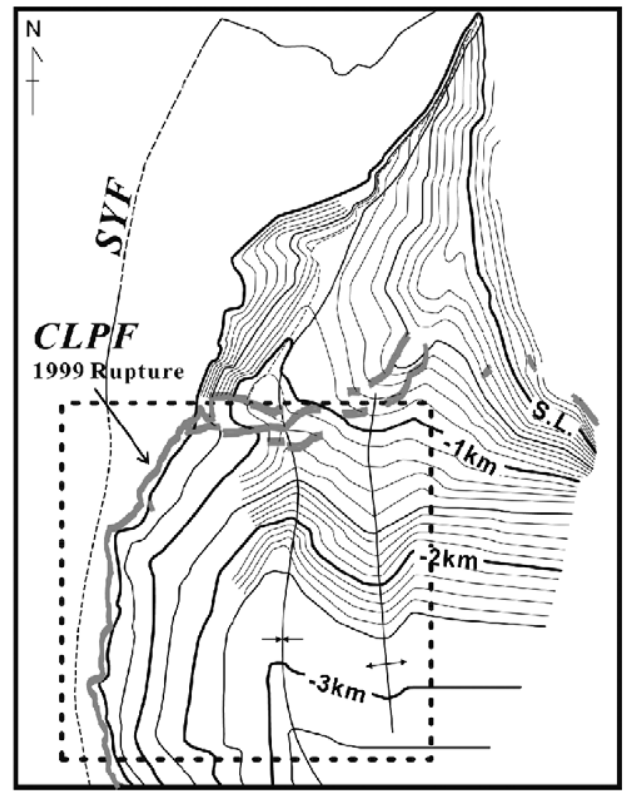

(A)

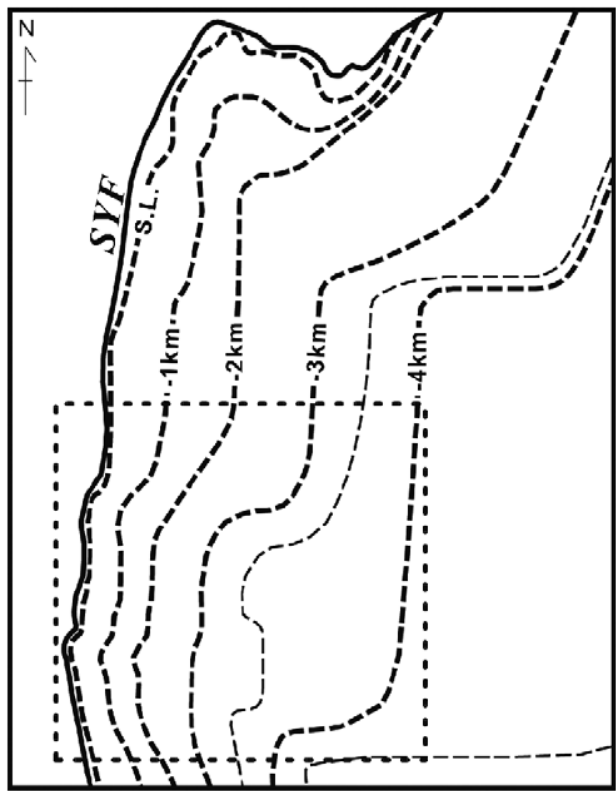

(B)

\section{Syncline SYF Sanyi Fault \\ $X$ Anticline CLPF Chelungpu Fault}

Fig. 11. (A) Model of Chelungpu fault slipping on the lower Pliocene shale (Chinshui shale). (B) Model of Sanyi fault slipping on the upper Miocene sandstone/shale (after Yue et al., 2005). Two fault models indicate that there are two different fault planes in the Sanyi-Chelungpu fault system in the study area. The contours show the depths of the lower Pliocene shale (Chinshui shale) in (A) and the upper Miocene sandstone/shale in (B) below sea level (S.L.). The dashed rectangles show the study area (Figs. 2 and 3).

Table 1

Estimation of the ages of terraces

\begin{tabular}{llll}
\hline & $\mathrm{LT}_{1}$ & $\mathrm{LT}_{2}$ & $\mathrm{LT}_{3}$ \\
\hline Elevation of uplifted segment & $580-620 \mathrm{~m}$ & $500-570 \mathrm{~m}$ & $470-480 \mathrm{~m}$ \\
Different elevation from footwall surface & $310-370 \mathrm{~m}$ & $230-320 \mathrm{~m}$ & $200-230 \mathrm{~m}$ \\
Paleo-surface compared to the present & $-43 \mathrm{~m}$ & $-35 \mathrm{~m}$ & $-28 \mathrm{~m}$ \\
Age & $55 \pm 12.6 \mathrm{ka}^{\mathrm{a}}$ & $40-48 \mathrm{ka}^{\mathrm{b}}$ & $34-36 \mathrm{ka}^{\mathrm{b}}$ \\
\hline
\end{tabular}

${ }^{\mathrm{a}}$ Data from OSL dating.

${ }^{\mathrm{b}}$ Data from computing.

supporting the model mentioned above. One is the vertical slips recorded by the GPS network, apparently larger on the eastern relative to the western bank of the Tachia River (Figs. 2, 6 and 7), indicating tilting coupled with the action of the Chelungpu fault. The other is that the fault-slip occurred along not only the main thrust at the western front but also in the Chinshui shale in the eastern limb of the large syncline in the hanging wall (Figs. 1 and 11). This implies that the entire subsurface Chinshui shale was involved in the fault action. Under this circumstance, the subsurface relief of the Chinshui shale presented in Fig. 11a should play a major role in governing the structural geometry and surface deformation.

\subsection{Deformation rate and terrace development age}

The deformations, including tilt and displacement of the Hsinshe terraces, are mainly governed by the movement of the Chelungpu fault. The higher terrace shows larger deformation, indicating that the influences of active structures on the terraces are continuous. We can give an average uplift rate from the OSL age of $55.0 \pm 12.6 \mathrm{ka}$ determined from the sample from the highest terrace. Since the cumulative height of the fold-scarp is ca. $135 \mathrm{~m}$ for the $\mathrm{LT}_{1}$ (Fig. 7A), the long-term vertical rate can be computed as $2.5 \mathrm{~m} / \mathrm{kyr}$. The vertical offset of the main thrust can be derived from the elevation difference between the surface of the highest terrace and the coeval paleo-ground surface of the footwall. The measured height difference is $310-370 \mathrm{~m}$ from $\mathrm{LT}_{1}$ to the modern ground surface of Fengyuan (Fig. 7 and Table 1). A core from Wufeng (BH-1 in Fig. 1; Chen and Chen, 2003) was used to determine the depth of the paleo-ground surface coeval to the $\mathrm{LT}_{1}$. Four OSL ages were determined from the core top, giving an accumulation rate of $0.81 \mathrm{~m} / \mathrm{kyr}$ (Fig. 12). Assuming the paleo-slope is similar to the modern one between Wufeng 


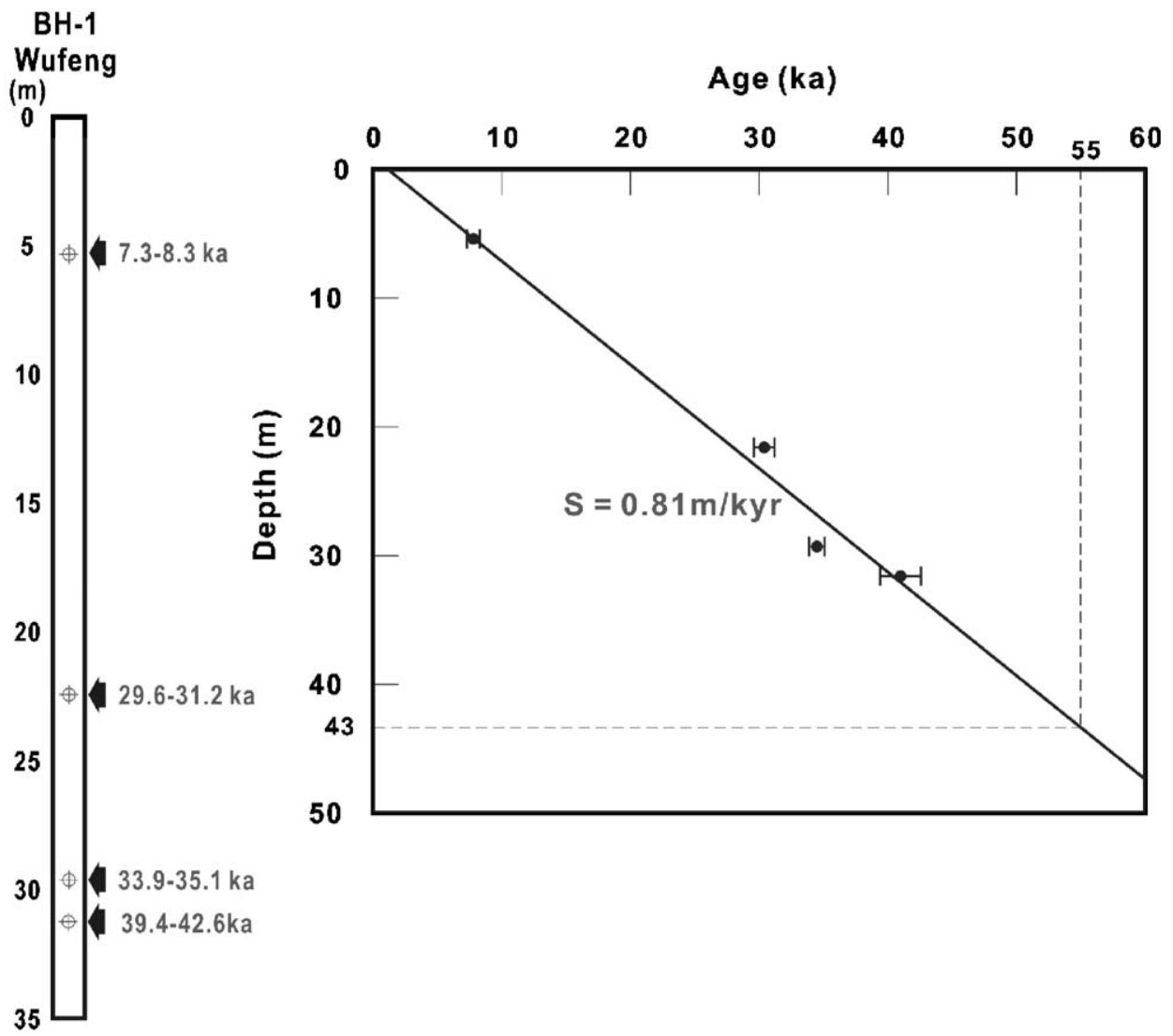

Fig. 12. Column in the left shows OSL ages of a shallow core (BH-1) drilled from Wufeng (Fig. 1a). Graph in the right shows the age-depth plot, giving an accumulation rate of $0.81 \mathrm{~m} / \mathrm{kyr}$. Therefore, the depths of paleo-ground surfaces of LT1 ( $55 \mathrm{ka}$ ) can be approximately estimated to the depth of $43 \mathrm{~m}$ if we assume the paleo-slope from Wufeng to Fengyuan is similar to present day.

and Fengyuan, the coeval paleo-ground surface of $\mathrm{LT}_{1}$ (i.e., $55 \mathrm{ka}$ ) is approximately at 43 in depth. Consequently, the main thrust has caused a vertical offset of ca. $383 \mathrm{~m}$ in total since $55 \mathrm{ka}$. The corresponding uplift rate can also be derived as $7.0 \mathrm{~m} / \mathrm{kyr}$. Based on the uplift rate of the main thrust, we can further estimate the development ages of the other two lateritic terraces, $\mathrm{LT}_{2}$ and $\mathrm{LT}_{3}$, as $40-48$ and 34-36 ka, respectively.

\section{Conclusions}

The Hsinshe terraces distributed in the hanging wall of the Chelungpu fault can be divided into three phases of widespread lateritic terraces $\left(\mathrm{LT}_{1}, \mathrm{LT}_{2}\right.$, and $\left.\mathrm{LT}_{3}\right)$ based on formation time. The higher terraces show larger deformation than the lower ones, demonstrating that these structures have been active for a long time.

E-W cross sections show that the Chelungpu fault plane flattens to the east, becomes shallower to the north, and terminates at the Tachia River as manifested by the 1999 surface ruptures. The bending of the fault plane at depth results in a monoclinal kink-shape in the strata of the hanging wall and produces a large fold scarp on the Hsinshe terrace surface.
Co-seismic vertical slip during the Chi-Chi earthquake was quite different across the kink-fold scarp. The action of the Chelungpu fault causes differential uplifting, and the large fold scarp can be explained by fault-bend kinetics.

The unusual back tilting of the terraces distributed in the eastern part of the hanging wall resulted from the singularity on the Chelungpu fault. This is supported by the rupture occurring along the Chinshui shale exposed in the eastern limb and the larger co-seismic vertical slips in the eastern bank of the Tachia River.

The OSL age of $55.0 \pm 12.6 \mathrm{ka}$ for the sample collected from $\mathrm{LT}_{1}$ gives average vertical slip rates of the main thrust and fold scarp in the hanging wall as 7.0 and $2.5 \mathrm{~m} / \mathrm{kyr}$, respectively.

\section{Acknowledgments}

We would like to thank Dr. Onno Oncken and Dr. Mark Handy for their helpful and valuable comments and suggestions. This research is financially supported by the National Science Council and Central Geological Survey of Republic of China under grant nos. NSC90-2119-M-002-009, NSC91-2119-M-002-024, and CGS5226902000-03-93-01. 


\section{References}

Bonilla, M.G., 1977. Summary of quaternary faulting and elevation changes in Taiwan. Memoir Geological Society of China 2, $43-55$.

CGS, 1999. Investigation Report of 921 Earthquake Geology and Map of Surface Ruptures along the Chelungpu Fault during the 1999 Chi-Chi Earthquake. Central Geological Survey, Ministry of Economic Affairs, Taiwan, Republic of China (in Chinese).

Chang, S.L., 1971. Subsurface geologic study of the Taichung basin, Taiwan. Petroleum Geology of Taiwan 8, 21-46.

Chen, W.S., Chen, Y.G., 2003. Plan for establishing a data bank on earthquake geology and information on active faults: trenching and paleoseismicity investigation (2/5) - TL and OSL dating. Central Geological Survey Report 92-7, 41pp (in Chinese).

Chen, Y.G., Chen, Y.W., Chen, W.S., Zhang, J.F., Zhao, H., Zhou, L.P., Li, S.H., 2003. Preliminary results of long-term slip rates of 1999 earthquake fault by luminescence and radiocarbon dating. Quaternary Science Reviews 22, 1213-1221.

Chen, Y.G., Chen, W.S., Lee, J.C., Lee, Y.H., Lee, C.T., Chang, H.C., Lo, C.H., 2001. Surface Rupture of 1999 Chi-Chi Earthquake Yields Insights on Active Tectonics of Central Taiwan. Bulletin of Seismological Society of America 91 (5), 977-985.

Chiu, H.T., 1971. Fold in the northern half of Western Taiwan. Petroleum Geology of Taiwan 8, 7-19.

Chou, J.T., 1971. A sedimentologic and paleogeographic study of the Neogene formation in the Taichung Region, western Taiwan. Petroleum Geology of Taiwan 9, 43-66.

Davis, D.J., Suppe, J., Dahlen, F.A., 1983. Mechanics of fold-and-thrust belts and accretionary wedges. Journal of Geophysics Research 88, $1153-1172$.
Ho, C.S., 1982. Tectonic Evolution of Taiwan-Explanatory Text of the Geologic Map of Taiwan. Central Geological Survey, Ministry of Economic Affairs, Taiwan, Republic of China 126pp.

Ho, C.S., Tan, L.P., 1960. Geology and coal deposit of the area between Tungshih, Taichung and Kuohsing, Nantou, Taiwan. Bulletin of the Geological Survey of Taiwan 12, 20-62.

Hsu, T.L., 1974. Fluvial landforms of northern Taiwan and their neotectonic significance. Bulletin of Geology Survey of Taiwan 24, 109-118.

Hung, J.H., Suppe, J., 2002. Subsurface geometry and kinematics of the Sani-Chelungpu thrust faults. Eos Transaction AGU, 83(22), Western Pacific Geophysics Meeting Supplement, Abstract SE441E-09.

$\mathrm{Ku}$, C.C., 1963. Photogeologic study of terraces in north-western Taiwan. Proceedings of Geological Society of China 6, 51-60.

Lin, C.C., 1957. Topography of Taiwan. Publication of the Taiwan Provincial Documentary Committee 424pp (in Chinese).

LSB, 1999. Vertical and Horizontal Displacements from GPS Measurements in the Chi-Chi Earthquake Hazard. Land Survey Bureau, Ministry of Interior, Taiwan, Republic of China.

Meng, C.Y., 1963. San-I overthrust. Petroleum Geology of Taiwan 2, 1-20.

Ota, Y., Lin, Y.N., Chen, Y.G., Chang, H.C., Hung, J.H., 2005. The Tunglo active fault system as deduced from deformed terraces, Central Taiwan, Tectonophysics, in revision.

Shih, T.T., Teng, K.S., Yang, K.S., Hsu, M.Y., 1986. Active faults and geomorphic surfaces of the Hsinshe terraces. Geomorphic Bulletin 5, 29-39 (in Chinese).

Teng, L.S., 1990. Geotectonic evolution of late Cenozoic arc-continent collision in Taiwan. Tectonophysics 183, 57-76.

Yu, S.B., Chen, H.Y., Kuo, L.C., 1997. Velocity field of GPS station in the Taiwan area. Tectonophysics 274, 41-59.

Yue, L.F., Suppe, J., Hung, J.H., 2005. Structural geology of a classic thrust belt earthquake: the 1999 Chi-Chi earthquake Taiwan $\left(M_{\mathrm{W}}=7.6\right)$. Journal of Structural Geology 27, 2058-2083. 